УДК 338.48.6:7/8(477.8)

\author{
Шевелюк Михайло Михайлович, \\ аспірант Київського національного \\ університету культури і мистецтв \\ ORCID: 0000-0001-6178-6455 \\ sheweluck.mih@gmail.com
}

\title{
ОСОБЛИВОСТІ РОЗВИТКУ СТРУКТУРНИХ КОМПОНЕНТІВ КУЛЬТУРНОГО ТУРИЗМУ ЛЬВІВЩИНИ
}

\begin{abstract}
Мета статті - з'ясувати особливості структурних компонентів розвитку культурного туризму Львівщини. Методологія дослідження. Для досягнення поставленої мети в роботі використано теоретичні та емпіричні методи гуманітарних досліджень, методи логічного і культурологічного аналізу. Наукова новизна полягає в з'ясуванні реалій та перспектив розвитку культурного туризму у Львівській області. Висновки. Розвиток культурного туризму Львівської області переважно грунтується на етно-фольклорному, історичному, зеленому видах туризму. Їх елементи присутні у більшості туристичних продуктів Львівщини (екскурсії, подорожі, відвідування історичних пам'яток і пам'ятних місць, музеїв, замків). Через включення складника історичного й культурного туризму у більшість туристичних продуктів Львівщини, його розвиток здатен зробити останні більш привабливими і слугувати ефективним рушієм зростання туристичної сфери. Водночас багатий природно-рекреаційний потенціал регіону приваблює i поціновувачів інших видів туризму (оздоровчого, спортивного тощо). Інституційною основою розвитку різних видів культурного туризму у Львівській області є динамічне соціокультурне життя міста Львова та інших населених пунктів краю. Активізація культурно-мистецьких подій національного і міжнародного (у межах регіонів країн Центральної і Східної Європи) рівнів може взаємно сприяти інтенсифікації різних видів туризму та ефективному використанню об'єктів культурної спадщини Львівської області.
\end{abstract}

Ключові слова: туризм, культурний туризм, дестинації, Львів, Львівщина.

Шевелюк Михаил Михайлович, аспирант Киевского национального университета культуры и искусств Особенности развития структурных компонентов культурного туризма львовщины

Цель статьи - выяснить особенности структурных компонентов развития культурного туризма Львовщины. Методология исследования. Для достижения поставленной цели в работе использованы теоретические и эмпирические методы гуманитарных исследований, методы логического и культурологического анализа. Научная новизна заключается в выяснении реалий и перспектив развития культурного туризма в Львовской области. Выводы. Развитие культурного туризма Львовской области преимущественно основывается на этно-фольклорном, историческом, зеленом видах туризма. Их элементы присутствуют в большинстве туристических продуктов Львовщины (экскурсии, путешествия, посещение исторических памятников и памятных мест, музеев, замков). За счет включения составляющей исторического и культурного туризма в большинство туристических продуктов Львовщины, его развитие способно сделать последние более привлекательными и служить эффективным двигателем роста туристической сферы. В то же время богатый природно-рекреационный потенциал региона привлекает и любителей других видов туризма (оздоровительного, спортивного и т.д.). Институциональной основой развития различных видов культурного туризма в Львовской области является динамическая социокультурная жизнь города Львова и других населенных пунктов края. Активизация культурных событий национального и международного (в пределах регионов стран Центральной и Восточной Европы) уровней может взаимно способствовать интенсификации различных видов туризма и эффективному использованию объектов культурного наследия Львовской области.

Ключевые слова: туризм, культурный туризм, дестинации, Львов, Львовская область.

Sheveliuk Mykhailo, Postgraduate student of Kyiv National University of Culture and Arts,

Peculiarities of development of the structural components of Lviv cultural tourism

The purpose of the article is to find out the peculiarities of structural components of the development of cultural tourism in the Lviv region. Methodology. To achieve this goal, theoretical and empirical methods of humanitarian research, methods of logical and cultural analysis were used. The scientific novelty is to find out the realities and prospects of cultural tourism development in the Lviv region. Conclusions. The development of cultural tourism in the Lviv region is predominantly based on ethnic-folk, historical, green types of tourism. Their elements are present in most tourist products of the Lviv region (excursions, trips, visits to historical monuments and monuments, museums, castles). Due to the inclusion of a component of historical and cultural tourism in most of the tourism products of the Lviv region, its development can make the latter more attractive and serve as an effective driver for the growth of the tourism sphere. At the same time, the rich natural and recreational potential of the region attracts connoisseurs of other types of tourism (wellness, sports, etc.). The institutional basis for the development of various types of cultural tourism in the Lviv region is the dynamic socio-cultural life of the city of Lviv and other settlements of

(СШевелюк М. М., 2019 
the region. The revitalization of cultural and artistic events of national and international (within the regions of Central and Eastern Europe) levels can mutually contribute to the intensification of different types of tourism and the effective use of objects of the cultural heritage of the Lviv region.

Key words: tourism, cultural tourism, destinations, Lviv, Lviv region.

Актуальність дослідження. Львівська область посідає одне із перших місць серед регіонів України за рівнем і потенціалом розвитку туристичної індустрії. На Львівщині розташовані туристичні ресурси, які дають змогу розвивати широкий спектр різновидів туризму, створюючи привабливі для туристів локації. Туристична галузь динамічно зростає і $є$ одним із найбільш перспективних напрямів розвитку економіки регіону, разом із тим успішна і повна реалізація туристичного потенціалу Львівщини $\epsilon$ можливою за умов забезпечення стійкості цього розвитку, що розуміється сучасними науковцями як здатність підтримувати якість фізичних, соціальних, культурних і природних ресурсів туристичної дестинації, що забезпечує іiі конкурентоспроможність на ринку $[18,329]$. Якість ресурсів туристичної дестинації має інституційну основу, що може забезпечуватися за умов наявності розвинених інститутів культурних, історичних, соціальних тощо.

Аналіз досліджень і публікацій. Проблема структурних компонентів розвитку туризму Львівщини порушується у численних дослідженнях, зокрема працях, автори яких аналізують стан і перспективи розвитку туризму в регіоні (М. Бігус та ін.) [2] та загалом політику розвитку туристичної сфери (О. Бєлуха та ін.) [1]. Значний масив наукових розвідок присвячений аналізу цієї проблеми у контексті питань розвитку окремих видів туристичної діяльності, зокрема культурного (О. Савіцька та ін) [16], ділового (П. Романів) [15], зеленого (І. Литвин та М. Нек), [10], військово-історичного (І. Голиборода) [6], подієвого (Д. Каднічанський) [8], ностальгійного (Р. Лозинський, І. Кучинський та Ю. Дорош) [11], приміського (Т. Біла) [3], етно-фестивального (Я. Топорницька) [17] тощо. Проблему соціальних умов розвитку туристичної дестинації, поряд із економічними, розглянуто у праці Ю. Леонтієвої та О. Тимощенкової [9]. На жаль, наявність структурних компонентів розвитку туризму часто не враховується в методиках оцінювання туристичного потенціалу дестинацій [4], виробленні бізнесстратегій просування дестинацій [5] та в картах SWOT-аналізу розвитку туристичної сфери регіону [12].

Мета статті - з'ясувати особливості структурних компонентів розвитку культурного туризму Львівщини.

Виклад основного матеріалу. Туристичний сектор Львівщини характеризується диверсифікованістю і наявністю можливостей для розвитку послуг у багатосезонному, внутрішньо- та зовнішньо-орієнтованому туризмі, також додатковим сприятливим чинником є якісна транспортна i соціальна інфраструктура регіону. Територія Львівської області характеризується помірним техногенним навантаженням - вона розташована на великому європейському водорозділі басейнів Балтійського та Чорного морів, iii третина представлена гірськими місцевостями із привабливими для туристів ландшафтами та наявними можливостями щодо лікування, спорту й рекреації [13, 147]. Область є місцем зосередження великої за обсягами культурної спадщини: у ній зареєстровані понад 4 тис. пам'яток історії та культури, із них більше половини розташовані у самому Львові, визнаному містом культурної спадщини ЮНЕСКО. Наразі в області діють 153 музеї різних форм власності, 10 театрів, а також функціонують понад 320 інших туристичних об'єктів й архітектурних пам'яток із високим рівнем відвідуваності та 37 природних комплексів [14]. При цьому внутрішні туристичні потоки переважають над зовнішніми: iз 2000 р. спостерігається стійка тенденція до зменшення зовнішнього туризму до Львівської області, зокрема у 2000-2017 рр. кількість зовнішніх туристів зменшилася у 3,9 разів. Тенденція щодо скорочення кількості внутрішніх туристів була перервана у 2015 р., коли відбувся перерозподіл туристичних потоків у межах країни (зокрема ті українські туристи, які раніше відвідували Крим, звернули свою увагу на західні регіони нашої країни, у т.ч. Львівщину) [8]. Крім того, сприятливим чинником для залучення туристів із країн Центральної та Східної Європи є розташування регіону на перехресті транспортних й історико-культурних комунікацій, які об'єднують Україну та Польщу, Словаччину, Угорщину, Румунію.

Сукупність цих умов дає змогу розглядати й аналізувати туристичний сектор Львівщини як галузевий кластер. Його туристичний потенціал, як сукупність матеріальних і нематеріальних ресурсів, які формують інтерес до певної території і $\epsilon$ основою для здійснення туристичної діяльності й формування туристичної пропозиції $[4,21]$, може бути реалізований лише за умови створення відповідних інституцій. Особливо це стосується культурного туризму, для якого певні інституції $\epsilon$ обов'язковою умовою становлення і розвитку.

Сучасні туристичні дестинації формуються на основі мультиресурсного потенціалу шляхом виокремлення і підкреслення «глокалізації», їх регіональної ідентичності [4]. Це відбувається свідомо і 
всупереч об’єктивній тенденції до зростання доступності дестинацій за одночасного зменшення їх індивідуальності, яка є наслідком ускладнення й технічного удосконалення засобів сполучення та інформаційних комунікацій [5]. У цілому, розглядаючи систему туристичної діяльності на Львівщині у контексті культурного туризму, можна стверджувати, що вона безпосередньо пов'язана 3 туристичним іміджем регіону, що формується за рахунок етно-фольклорного, історичного та зеленого туризму. Так, попри те, що етно-фольклорний, або фольклорний, туризм часто не представлений окремими спеціалізованими туристичними продуктам, як компонент він присутній у широкому спектрі наявних на сучасний момент туристичних продуктів (турів, екскурсій тощо). Етно-фольклорний туризм спирається на туристичний імідж Львівщини як української історичної землі, одного із носіїв української національної ідентичності, «Українського П’ємонту» (разом з Івано-Франківщиною і Тернопільщиною), місця дій сил спротиву комуністичному режиму (разом з іншими регіонами Східної Галичини й Західної України у цілому). Компонентом туристичного іміджу Львівщини також є образ Львова як культурної столиці Західної України та зберігача традицій вікової культури, пов'язаною із Габсбурзькою імперією. Щодо своєї етнокультурної специфіки Львівщина є поєднанням культур ії традиційних національних громад - польської, вірменської, єврейської, німецької тощо. Це відображається у перейнятті і взаємовпливові традицій, в особливостях етнографії і фольклору. Численні на Львівщині пам'ятки, які належать до історичної спадщини етнічних громад краю, стають об'єктами ностальгійних турів, які також можна віднести до етно-фольклорного різновиду культурного туризму [11].

Важливою складовою культурного туризму $є$ зелений туризм (синоніми - сільський туризм, агротуризм, екотуризм) $[10,82]$, який є поширеним у світовій практиці засобом розвитку сільських територій, а також економічної і соціальної підтримки традиційних форм життя у сільській місцевості. В Україні, у т.ч. в Львівській області, ситуація із зеленим туризмом $є$ неоднозначною, оскільки організований зелений туризм у нашій країні поки не розвинений. Разом із тим, потенціал для розвитку зеленого туризму на Львівщині є вельми значним. Попри те, що висока питома вага територій, які використовуються у сільському господарстві, створюють дефіцит придатних для туристичного використання природних ландшафтів, мережа територій-резервацій природнього середовища на Львівщині $є$ досить щільною. У Львівщині розташований природний заповідник «Розточчя» площею 2084,5 га, два національні природні («Яворівський», «Сколівські Бескиди») та три ландшафтні парки («Верхньодністровські Бескиди», «Надсянський», «Знесіння»), а також 37 заказників. Також до мережі природних резервацій відносяться 48 заповідних урочищ, 261 парки - пам'ятки садово-паркового мистецтва та 176 пам'яток природи, що загалом формує значні потенційні можливості для розвитку зеленого туризму $[12,125]$. На Львівщині також сформовані регіональні кластери зеленого туризму «Оберіг», «Кам’янець», «Екотур». На жаль, в області актуальним є брак сучасної культури використання гірських і лісових територій, що обумовлюється рядом складних фінансово-економічних і соціальних чинників, зокрема безробіттям населення. Перспективи для вирішення цих та інших проблемних аспектів пропонує децентралізація в Україні, яка супроводжується посиленням територіальних громад (у т.ч. підвищенням їх фінансової самостійності) й відродженням місцевої культури.

Ефективність розвитку культурного туризму безпосередньо залежить від діяльності закладів культури й мистецтва, розвитку ділових зв'язків тощо. Так, ділові зв'язки у межах культурного туризму охоплюють індустрію MICE - «Meetings, Incentives, Conferences, Exhibitions». На практиці вони включають широке коло можливих заходів у напрямах громадських контактів (візити, з'їзди), наукових подій (конференції, семінари, симпозіуми, конгреси), комерційних презентацій (виставки, ярмарки), професійних та інших контактів [15, 212]. На Львівщині організатором бізнес-подій часто виступає «Клуб ділових людей», у м. Трускавець із 2002 р. проводиться традиційний регіональний бізнес-форум [8, 178]. Крім розвитку ділових зв'язків, збільшення туристичних потоків до Львівщини стимулюється, зокрема, програмами транскордонного співробітництва у просуванні та розвитку культурного туризму. У цьому контексті знаковим для Львова був Міжнародний проект «Східноєвропейські перлини: створення та просування продуктів міського культурного туризму в транскордонному просторі», який об'єднав шість міст - Львів, Івано-Франківськ, Коломию та польські міста - Люблін, Замостя, Пшеворськ. Проект був частиною більш широкої програми транскордонного співробітництва України, Польщі та Білорусі і мав за мету просування міського культурного туризму.

Характерною особливістю культурної політики Львова є організація фестивальних заходів, які $є$ формою відзначення традиційних свят: «Різдво у Львові», «Флюгери Львова», «Етновир», Свято кави тощо) $[16,379-380]$. Протягом року у місті проходять дев'ять великих і значна кількість локальних міських і сільських свят, які мають етнографічну, історичну, екологічну спрямованість. Зокрема, це етнофестиваль «Підкамінь» (с. Підкамінь Брдівського району), екологічний «Верхобуж» (с. Верхобуж) та історичний фестиваль «Ту стань!» (с. Урич Сколівського району), фестивалі лемківської культури «До 
тебе лину, рідна земле» (с. Нагірне, Самбірського району), української слави «Кульчиці-фест» (с. Кульчиці Самбірського району) $[8,176]$. Ці фестивалі охоплюють усю територію області, утім в їх географічній локації можна виокремити два ареали - Львів та його околиці і Передкарпатський субрегіон $[17,94]$. Загалом, за висновком Д. Каднічанського та І. Грицюка, для сучасної фестивальної культури Львівщини визначальною є орієнтація на молодого туриста, звернення до культурних традицій та етнографічної спадщини регіону, різноманітність і спеціалізація, а також патріотичне спрямування [8, 177-178]. Ряд фестивалів має виразне етно-фольклорне забарвлення, як от Міжнародний фестиваль молодих виконавців сучасної української пісні «Молода Галичина» у м. Новояворівському, де нова фестивальна традиція спирається на унікальну місцеву пісенну традицію та характерні для краю традиційні декоративно-прикладні мистецтва $[17,94]$.

Насамкінець варто наголосити, що культурний туризм $є$ широко представленим у туристичних продуктах, які пропонують ознайомлення зі Львівською областю не лише як місцем унікальної міської культури, а й як територією для відпочинку в гірській місцевості (Славське, Волосянка, Тисовець, Орявчик та ін.). Важливо також вказати про вагому роль у формуванні туристичного потенціалу Львова бренду «традиційної львівської гостинності». Безсумнівно, у межах України набув поширення імідж Львівщини, який сформувався на регіональних особливостях побутової культури, зокрема культура спілкування жителів регіону розглядається як вияв традиційної ввічливості, яка створює основу для комфортного спілкування туристів. Ці ж міркування справедливі не лише щодо культурного, а й лікувально-оздоровчого туризму, оскільки цей вид туризму передбачає відносно тривале (з оздоровчими цілями) перебування туристів у курортних містах і селах Львівщини (Трускавці, Моршині, Сходниці, Немирові та ін.), що передбачає ознайомлення і з місцевою культурною спадщиною.

Висновки. Таким чином, розвиток культурного туризму Львівської області переважно грунтується на етно-фольклорному, історичному, зеленому видах туризму. Їх елементи присутні у більшості туристичних продуктів Львівщини (екскурсії, подорожі, відвідування історичних пам'яток і пам'ятних місць, музеїв, замків). Через включення складника історичного й культурного туризму у більшість туристичних продуктів Львівщини, його розвиток здатен зробити останні більш привабливими $\mathrm{i}$ слугувати ефективним рушієм зростання туристичної сфери. Водночас багатий природно-рекреаційний потенціал регіону приваблює і поціновувачів інших видів туризму (оздоровчого, спортивного тощо).

Інституційною основою розвитку різних видів культурного туризму у Львівській області $€$ динамічне соціокультурне життя міста Львова та інших населених пунктів краю. Основа туристичної привабливості Львова та області - унікальний культурно-історичний спадок вказаного регіону, що формує його неповторну атмосферу. У цьому контексті активізація культурно-мистецьких подій національного і міжнародного (у межах регіонів країн Центральної і Східної Свропи) рівнів може взаємно сприяти інтенсифікації різних видів туризму та ефективному використанню об'єктів культурної спадщини Львівської області.

Означена тема, безсумнівно, має значні перспективи для подальших досліджень, серед яких, зокрема - здійснення компаративного аналізу потенціалу розвитку культурного туризму в Львівській області та інших регіонах Західної України (зокрема в Івано-Франківській і Тернопільській областях, які спільно із Львівщиною формують історико-географічний регіон Східна Галичина).

\section{Jimepamypa}

1. Бєлуха О. М., Павліш Л. В. Розвиток туристичної галузі Львівської області в контексті реалізації регіональної туристичної політики. Науковий вісник НЛТУ України. 2012. № 7. С. 38-43.

2. Бігус М. М. Аналіз сучасного стану туристичного бізнесу Львівщини у контексті глобалізаційних процесів. Науковий вісник Міжнародного гуманітарного університету. Серія : Економіка і менеджмент. 2015. Вип. 14. С. 124-128.

3. Біла Т. П. Приміський туризм м. Львів. Географія та туризм. 2012. Вип. 19. С. 121-130.

4. Бойко М. Диференціація туристичного потенціалу дестинацій. Вісник Київського національного торговельно-економічного університету. 2013. № 5. С. 19-30.

5. Влащенко Н. М. Брендинг та просування туристської дестинації на основі транскордонного співробітництва. Економічний форум. 2016. № 3. С. 92-97.

6. Голиборода I. Перспективи розвитку військово-історичного туризму на Львівщині. Вісник Львівського університету. Серія : Міжнародні відносини. 2012. Вип. 29 (2). С. 45-50.

7. Головне управління статистики у Львівській області. URL: http://www.lv.ukrstat.gov.ua.

8. Каднічанський Д. А., Грицюк I. М. Стан та перспективи розвитку подієвого туризму у Львівській області. Географія та туризм. 2012. Вип. 20. С. 174-184.

9. Леонтьева Ю. Ю., Тимощенкова О. А. Региональная туристская дестинация и её социальноэкономическое развитие. Бізнес Інформ. 2013. №6. С. 165-170. 
10. Литвин І. В., Нек М. О. Проблеми та перспективи розвитку сільського зеленого туризму в регіоні. Регіональна економіка. 2013. № 2. С. 81-88.

11. Лозинський Р. М., Кучинська І. В., Дорош Ю. С. Географія ресурсів ностальгійного туризму Жовківського району Львівської області. Карпатський край. 2013. № 1. С. 94-101.

12. Павліш Л. В. Львівщина як перспективний регіон України для розвитку туризму та рекреації. Торгівля, комерція, підприємництво. 2013. Вип. 15. С. 124-128.

13. Паньків Н. Аналіз передумов і сучасного стану розвитку туристичної галузі Львівської області. Вісник Львівського університету. Серія : Міжнародні відносини. 2012. Вип. 29 (1). С. 146-158.

14. Рекреаційний потенціал Львівщини: Статист. збірник / Головне управління статистики у Львівській обл., Відпов. за вип. Н. І. Бонк. Львів: Головне управління статистики у Львівській області, 2012. 96 с.

15. Романів П. Діловий туризм у Львівській області проблеми та перспективи організації. Вісник Львівського університету. Серія : Міжнародні відносини. 2012. Вип. 29 (2). С. 211-219.

16. Савіцька О. П., Марущак М. В. Культурний туризм: реалії та перспективи розвитку у Львівській області. Науковий вісник НЛТУ України. 2014. Вип. 24 (1). С. 376-383.

17. Топорницька М. Я. Територіальна організація та перспективи розвитку етнофестивального туризму у Львівській області. Географія та туризм. 2012. Вип. 21. С. 89-96.

18. Goeldner C. R., Ritchie J. R. B. Ritchie. Tourism: principles, practices, philosophies. Hoboken, NJ: Wiley, 2012. 494 p.

\section{References}

1. Bielukha, O. M., Pavlish, L. V. (2012). Rozvytok turystychnoi haluzi Lvivskoi oblasti v konteksti realizatsii rehionalnoi turystychnoi polityky. Naukovyi visnyk NLTU Ukrainy. № 7. S. 38-43 [in Ukrainian].

2. Bihus, M. M. (2015). Analiz suchasnoho stanu turystychnoho biznesu Lvivshchyny u konteksti hlobalizatsiinykh protsesiv. Naukovyi visnyk Mizhnarodnoho humanitarnoho universytetu. Seriia : Ekonomika $i$ menedzhment. Vyp. 14. S. 124-128 [in Ukrainian].

3. Bila, T. P. (2012). Prymiskyi turyzm m. Lviv. Heohrafiia ta turyzm. Vyp. 19. S. 121-130 [in Ukrainian].

4. Boiko, M. (2013). Dyferentsiatsiia turystychnoho potentsialu destynatsii. Visnyk Kyivskoho natsionalnoho torhovelno-ekonomichnoho universytetu. № 5. S. 19-30 [in Ukrainian].

5. Vlashchenko, N. M. (2016). Brendynh ta prosuvannia turystskoi destynatsii na osnovi transkordonnoho spivrobitnytstva. Ekonomichnyi forum. № 3. S. 92-97 [in Ukrainian].

6. Holyboroda, I. (2012). Perspektyvy rozvytku viiskovo-istorychnoho turyzmu na Lvivshchyni. Visnyk Lvivskoho universytetu. Seriia : Mizhnarodni vidnosyny. Vyp. 29 (2). S. 45-50 [in Ukrainian].

7. Holovne upravlinnia statystyky u Lvivskii oblasti. URL: http://www.lv.ukrstat.gov.ua [in Ukrainian].

8. Kadnichanskyi, D. A., Hrytsiuk, I. M. (2012). Stan ta perspektyvy rozvytku podiievoho turyzmu u Lvivskii oblasti. Heohrafiia ta turyzm. Vyp. 20. S. 174-184 [in Ukrainian].

9. Leonteva, Yu. Yu., Tymoshchenkova, O. A. (2013). Rehyonalnaia turystskaia destynatsyia y eë sotsyalnoэkonomycheskoe razvytye. Biznes Inform. №6. S. 165-170 [in Ukrainian].

10. Lytvyn, I. V., Nek, M. O. (2013). Problemy ta perspektyvy rozvytku silskoho zelenoho turyzmu v rehioni. Rehionalna ekonomika. № 2. S. 81-88 [in Ukrainian].

11. Lozynskyi, R. M., Kuchynska, I. V., Dorosh, Yu. S.(2013). Heohrafiia resursiv nostalhiinoho turyzmu Zhovkivskoho raionu Lvivskoi oblasti. Karpatskyi krai. № 1. S. 94-101 [in Ukrainian].

12. Pavlish, L. V. (2013). Lvivshchyna yak perspektyvnyi rehion Ukrainy dlia rozvytku turyzmu ta rekreatsii. Torhivlia, komertsiia, pidpryiemnytstvo. Vyp. 15. S. 124-128 [in Ukrainian].

13. Pankiv, N. (2012). Analiz peredumov i suchasnoho stanu rozvytku turystychnoi haluzi Lvivskoi oblasti. Visnyk Lvivskoho universytetu. Seriia : Mizhnarodni vidnosyny. Vyp. 29 (1). S. 146-158 [in Ukrainian].

14. Rekreatsiinyi potentsial Lvivshchyny: Statyst. zbirnyk (2012). Lviv: Holovne upravlinnia statystyky u Lvivskii oblasti [in Ukrainian].

15. Romaniv, P. (2012). Dilovyi turyzm u Lvivskii oblasti problemy ta perspektyvy orhanizatsii. Visnyk Lvivskoho universytetu. Seriia : Mizhnarodni vidnosyny. Vyp. 29 (2). S. 211-219 [in Ukrainian].

16. Savitska, O. P., Marushchak, M. V. (2014). Kulturnyi turyzm: realii ta perspektyvy rozvytku u Lvivskii oblasti. Naukovyi visnyk NLTU Ukrainy. Vyp. 24 (1). S. 376-383 [in Ukrainian].

17. Topornytska, M. Ya. (2012). Terytorialna orhanizatsiia ta perspektyvy rozvytku etnofestyvalnoho turyzmu u Lvivskii oblasti. Heohrafiia ta turyzm. Vyp. 21. S. 89-96 [in Ukrainian].

18. Goeldner, C. R., Ritchie, J. R. B. (2012). Ritchie. Tourism: principles, practices, philosophies. Hoboken, NJ: Wiley.

Стаття надійшла до редакиії 27.10.2019 p. 